JERZY EISLER

Institute of National Remembrance, Warsaw

\title{
THE PEOPLE'S REPUBLIC OF POLAND - A SKETCH FOR REFLECTIONS ON THE LAICIZATION OF THE STATE
}

\begin{abstract}
The intention of this article is to consider, and attempt to resolve questions whether and to what degree the laicization policy and atheization campaign conducted by communists in Poland after the Second World War contributed to the de-Christianization of Polish society, a process observed also in other European countries. Ke y w ords: atheization, laicization, de-Christianization, communist regime, Catholic Church, Stefan Wyszyński, Church-state relations.
\end{abstract}

This essay looks at the manner and the possible extent to which the policy pursued by the political establishment in the period of the People's Republic of Poland (PRL) contributed to the laicization and secularization of the state, and atheization of the public life in Poland. The degree to which these processes coincided with the laicization of societies in the West, or in broader terms - with the often-raised issue of de-Christianization of Europe is also examined. All the terms mentioned above (possibly, except for de-Christianization) are defined one with another in various language dictionaries published in the era of PRL, ${ }^{1}$ which means that they were considered synonymous. The otherwise important question whether the definitions in their existing wording are the product of the PRL ideology or result from the adopted methodology remains unanswered. I admit that the general meaning of the terms, or even more their explanations, could

${ }^{1}$ For example see: Encyklopedia katolicka, 20 vols, ed. Feliks Gryglewicz et al., Lublin, 1973-2014; Władysław Kopaliński, Słownik wyrazów obcych i zwrotów obcojęzycznych, 11th edn, Warsaw, 1998; Religia. Encyklopedia PWN, 10 vols, scientific ed. Tadeusz Gadacz and Bogusław Milerski, Warsaw, 2001-03; Słownik języka polskiego, 3 vols, ed. Mieczysław Szymczak, Warsaw, 1978-81; Słownik języka polskiego, 11 vols, ed. Witold Doroszewski, Warsaw, 1964-69 (1996-97). 
have carried an ideological charge - after all, religion and the Catholic Church were considered an antagonistic phenomenon/institution.

Nevertheless, with all the necessary reservations and restrictions, I will use the terms synonymously as well. ${ }^{2}$ Before moving on to the proper discussion, let me refer to a personal experience.

In the years 1994-97 I held the post of the principal at the Adam Mickiewicz Primary and Secondary School at the Embassy of the Republic of Poland in Paris. My four daughters attended not only this school, which - in practice - operated two days a week, ${ }^{3}$ but they also studied in French schools at their respective educational levels. At the beginning of every school year, as their father, I had to sign their school report books below a printed sentence in the following wording: 'A lay and secular school forms the foundation of the Republic'. My signature was an acknowledgement of that principle, fundamental for France's political system. At the same time, the obligation to sign this type of ideological, or even worldview-related declaration, made me compare the Fifth Republic with the People's Republic of Poland - in a superficial but meaningful way.

${ }^{2}$ The term secularization - synonymous to laicization - originates from the Latin word scecularis (secular) and, in general, means the taking over of property, offices or territories by secular authorities from church authorities. Another meaning of the term is the transfer of a coenobite to the lay clergy, or returning of a clergyman to lay status. Laicization, on the other hand, in the political sense, is defined as limitation by the state of the influence of the Church and religion by means of legal acts, under which the Church and the state become separated (seizure of Church property, secularization of schools, and so on). In the sociological sense, laicization is the weakening of religious bonds, in particular a drop in the attendance to religious practices, turning away from the ethical and moral standards proclaimed by the Church, and diminishing of the clergy's authority. In the psychological sense, laicization is manifested through a change in the outlook on life, that is turning away from religion to agnosticism, atheism or indifferentism. The word 'atheism', of Greek origin ( $a-$ - 'non', theos - 'God'), seems stronger and more negative to many people; in practice, it means the negation of the existence of God. Four different forms of atheism are distinguished: dogmatic atheism, which explicitly negates the existence of God, sceptical atheism, based on the fact that God's existence cannot be proven, thus close to agnosticism, and practical atheism, which negates the importance of the problem whether God exists. Atheism is often identified with non-religiousness or impiety. For example, the term 'atheism' was used to refer to an attitude objecting the state religion and official Church, religious indifferentism, axiological relativism, an 'escape from religion' to privacy, and so on. Any signs of de-sacralization of life and dying out of religious practice were considered 'atheistic' or 'atheizing'.

${ }^{3}$ In those times, classes in the Polish School in Paris were held at the time when French schools were closed, that is on Wednesdays from 7:50 am to 8:10 pm and on Saturdays from 12:00 pm to 8:10 pm. 
As a matter of fact, ironically, I have always considered these two comparable and incomparable at the same time. The comparison of a democratic and liberal state with a state dependent on the adjacent superpower and governed by a dictatorship sounds rather awkward. We must not forget that a strong wave of laicization swept through France at the turn of the twentieth century and peaked in 1905, when the law of separation of Church and state was adopted. It was when the prime minister Emile Combes went as far as to sequestrate Church's property and possessions. All priests in religious orders were prohibited from teaching, and about 1,600 monastic houses were closed. ${ }^{4}$

With time, the revolutionary anti-clerical spirit waned, thwarted by, among other things, the traumatic experience of France and the French people during the First World War. It must be borne in mind that the political and social background of secularization of the public life in France was part of the modernization of the state. In Poland, on the other hand, a wave of government-driven anti-clerical attitudes came five decades later and was even more violent. What is more, laicization and secularization of Poland after the Second World War were part of an entirely different project, aimed to transform the reality and create a 'new man' - ultimately - free from the 'religious miasma'. The French state authorities abstained from prohibiting religious practice, whereas the PRL government aimed to quash it altogether. Therefore, although with some similarities, the two processes were embedded in utterly disparate political and social contexts.

In post-war Poland, the process was not aimed at merely separating Church and state, but at marginalizing, and ultimately wiping out the former. The Catholic Church embodied numerous ethical, moral and cultural values contradictory to the vision of the 'new man', and there was no room for a peaceful coexistence. Catholic social teaching stood utterly in contradiction to the vision pursued by the new authorities. Among those two completely different worlds, there was room for only one of them - the socialist one. I daresay that in the PRL, the goal, measures and methods were totalitarian, as they were tailored to bring about a total change. In France, laicization and secularization, even in the fiercest phase at the turn of the twentieth century, were carried out within a democratic and liberal state, in circumstances which must have mitigated the radical anti-clerical attitudes.

\footnotetext{
${ }^{4}$ Janusz Makowski, Kościót Francji. Wśród kontrowersji i osiagnięć katolicyzmu francuskiego, Warsaw, 1969, p. 18.
} 
Perhaps owing to the fact that the fight for a 'lay and secular Republic' was not unconstrained, of all the cities in the world, Paris is probably the one with the record number of squares, boulevards, alleys, streets, passages and backstreets named after saints - Saint-Denis, Saint-Germain, Saint-Honoré, Saint-Michel, Saint-Placide or Saint-Sulpice, to name just a few. The interesting thing is that nobody in France came up with the idea to remove the adjective 'Saint' from the names of streets or squares, and even if so - did not manage to force it through. In the PRL, however, the authorities did not hesitate to strip the streets named after Saint Barbara, Saint Boniface or Saint Vincent in Warsaw of the 'Saint' part. Many other Polish cities saw the same procedure, and some streets were even given completely different names. For example, one of the main streets in Poznań, Saint Martin (as an exception, against the Polish grammar rules - in the nominative rather than genitive case), was called Red Army Street in the PRL era. A comparison between the 'saint' streets in post-war Poland and France shows that the political leaders of the Fourth and Fifth ('lay and secular') Republics were much more reserved and tolerant in this respect than those in the PRL. We must not forget, however, that the renaming of streets, as well as numerous other governmental initiatives, had a systemic character and were part of a process aimed to create a secular state and shape a new, socialist citizen.

The observation becomes even more obvious when we recall how the government of the People's Republic of Poland 'interfered' in the world's ancient history and struggled, successfully in the end, to introduce into the public discourse (mass media, school education at all levels, scientific research, publications) the expressions 'before our era' (przed nasza era p.n.e.) and 'of our era' (naszej ery - n.e.) instead of the commonly used in Poland before the Second World War 'before Christ' (przed narodzeniem Chrystusa - prz. nar. Chr., Lat. ante Christum natum). In France (as well as in Great Britain), nobody has ever objected the use of avant Jesus Christ or après Jesus Christ - expressions still in use today.

The comparison between the Polish communists and France are at least equally unfavourable for the former when we analyse the issue of broadcasting the Sunday church service on the radio and television, addressed mostly, but not only, to elderly, ill and disabled citizens. In the 1970s, when nobody in Poland even dreamt of such radio broadcasts, the national TV in France broadcast the Sunday church service every week, not to mention the ample selection of regional and national French Catholic press. In the PRL, on the other hand, radio broadcasts of the Sunday church service, postulated as one of the twenty-one demands by the protesters in the August 1980 strikes in the Vladimir Lenin Shipyard in Gdańsk, were launched sev- 
eral weeks later, after 'social pacts' had been signed in Szczecin, Gdańsk and Jastrzębie.

For decades, broadcasting the Sunday service had been unimaginable, considering that for several years during the Stalinist period the Polish national radio broadcaster Polskie Radio was prohibited from playing Christmas carols. When the Polish Radio started to play Christmas carols again at Christmas 1954, the memo drawn up for the Organizational Division of the Polish United Workers' Party (Polska Zjednoczona Partia Robotnicza - PZPR) Central Committee in January 1955, concerning the reports on the public moods, sent in by the provincial committees, reported that in the Kielce province "people have been commenting on the fact of broadcasting Christmas carols on the radio, they view it as a forecast of some changes'. ${ }^{5}$ Before long, they were to discover how right the hunch was.

By the way, it is hard to say whether the fact that Christmas carols were not played on the radio, or that children as young as in kindergarten or first years of the primary school were strongly indoctrinated, was more to blame for the funny situations during Christmas carol singing with their families. In 2009, Teresa Bogucka recalled a situation which occurred years ago: 'There was a kindergarten run by nuns in Maków Podhalański, where I lived. The nuns were already under a lot of pressure [from the authorities] and were being tested in various ways. I used to go home from the kindergarten indoctrinated in the spirit of Bolshevism. My grandfather fulminated that it was a scandal. [...] One day, when we were singing Christmas carols, a tremendous row was kicked up, because I sang "Virgin Mary, Virgin Mary is cradling her Child, and Joseph Stalin, and Joseph Stalin, is watching over Him". My family realised that something was wrong, my patriotic grandmother made a terrible scene to my mother, that this was similar to something'. ${ }^{6}$ It seems that this type of 'Freudian error' was an after-effect

5 'Ludność komentuje fakt nadawania przez radio kolęd, widząc w tym zapowiedź jakiś zmian', as cited in: Zbysław Rykowski and Wiesław Władyka, Polska próba. Październik '56, Cracow, 1989, p. 87.

6 'W Makowie Podhalańskim, gdzie mieszkałam, było przedszkole prowadzone przez zakonnice. No i te zakonnice już były mocno naciskane [przez władze] i poddawane takim sprawdzającym testom. Przychodziłam naładowana bolszewizmem z tego przedszkola. Mój dziadek pomstował po prostu, że to absolutny skandal. [...] Kiedyś przy śpiewaniu kolęd wybuchła awantura, ponieważ zaśpiewałam "Maria Panna, Maria Panna dzieciątko piastuje, a Józef Stalin, a Józef Stalin ono pielęgnuje”. Więc rodzina po prostu dostrzegła, że się coś tutaj pomieszało, babcia patriotyczna zrobiła straszliwą awanturę mojej mamie, że do czego jest to podobne', Piotr Osęka, My, ludzie $z$ Marca. Autoportret pokolenia '68, Wołowiec, 2015, p. 68. What is interesting, it was not a one-off case. Marek Jodłowski recalled how, in his childhood 'the church resonated with the sound of Christmas carols. The organ sounded, men hooted, women led the 
of the strong propaganda pressure which affected even young children and influenced their subconscious minds.

Today, we often hear that laicization and/or secularization of Europe is gaining speed and momentum. It is hard to say unequivocally whether this view is fully correct. However, before I make an attempt to answer this question, let me draw your attention to two facts. Throughout Europe, from Portugal to Russia and from Norway to Greece, ambulances are visibly marked with a red cross. During a war, all health care facilities, such as hospitals, ambulances, medical trains and ships, are designated with a red cross located in a visible spot (for egzample on the roof). Such was the practice in the Third Reich, and even in Stalin's Soviet Union - medical facilities and vehicles were not marked with, respectively, a swastika or a red star, but with a red cross. Obviously, whether anyone in the Soviet Union pondered over the origin and symbolic meaning of this sign, borrowed from the broadly understood Christian tradition, remains unclear.? In Islamic countries (and even in the Asian Soviet republics, in the south of the Soviet Union), facilities and vehicles used by health care services were marked with a red crescent, and in Israel - with the red star of David. ${ }^{8}$

Secondly, let me recall that in many European countries, including Poland, the most honourable orders and national distinctions, especially battle medals, are in the shape of a cross, to mention the Virtuti Militari or the Polish Cross of Valour. Supposedly, similarly to the red cross, used as an explicit symbol by various medical services which save people's health

tune with their silvery voices. I could hear the words reach my ear: "and Joseph Stalin, and Joseph Stalin is watching over Him" [...]. It was surprising, but not shocking. Only later did I understand that it was me who replaced old Joseph with the generalissimo' ('kościół rozbrzmiewał śpiewem kolęd. Grzmiały organy, pohukiwali mężczyźni, srebrzystą nić melodii adorowały kobiety. Spod plafonu dobiegały słowa: "I Józef Stalin i Józef Stalin jemu kolęduje" [...]. Zdziwiło mnie to, ale nie za bardzo. Dopiero później zrozumiałem, że to ja sam Józefa Starego zastąpiłem generalissimusem'), as cited in: Robert Kupiecki, 'Natchnienie milionów'. Kult Józefa Stalina w Polsce 1944-1956, Warsaw, 1993, p. 139.

${ }^{7}$ Its origin is much more complex, since not only Christianity referred to the symbol of cross. Many references have been made to the fact that the symbol of the Red Cross against the white background was legally established in 1864, when the First Geneva Convention for the Amelioration of the Condition of the Wounded in Armies was adopted. The symbol of the Red Cross was based on the 'reversed' flag of Switzerland: the white cross against the red background, which refers to the Swiss battle medals from late medieval ages.

${ }^{8}$ Taking into consideration the religious connotations of these symbols, in 2007 , a new protective sign was introduced into international law. The Red Cristal is not associated with any religion - Christianity, Islam, Judaism, or any other. It is aimed to function along the symbols which have been in use so far rather than replace them. It is too early to determine where, when and in what scope it will catch on. 
and lives but often deal with death and the transcendence of life and death (especially in the time of war), the military cross (often awarded posthumously) is also meant to refer to the Christian tradition of suffering and sacrifice.

Let me now move on to the People's Republic of Poland and the relations connecting, or rather dividing, the governing communists from the Catholics, especially the Catholic men of the cloth. I am not going to discuss the relations between the state and the Church in the communist era, which have been described on many occasions in various ways and great detail. ${ }^{9}$ Instead, I will focus on the very clash of those two extremely disparate visions of the world. Notwithstanding the periods of political 'frost and thaw', which brought certain changes, anti-clericalism in its broadest meaning was one of the fundamentals of the communist regime throughout the communist era. In spite of all the tactical differences between the consecutive political teams, the relations between the state and the Church were difficult or very difficult throughout the period (maybe with the exception of the last ten years of the PRL). Only in the first three years of the People's Republic of Poland and at the turn of 1957-58, for short-term tactical reasons, did the communists refrain from attempts to, not so much laicize the state and society, as completely atheize public life.

It was only after Cardinal Karol Wojtyła had been elected Pope that certain long-term, as history showed, changes occurred. ${ }^{10}$ From today's perspective, the circumstances of the Pope's pilgrimages to Poland in 1979, 1983 and 1987 are recalled with distaste and amazement. Attempts were

${ }^{9}$ From hundreds of publications dealing with this subject, the following are worth a reference: Anna Anusz and Andrzej Anusz, Samotnie wśród wiernych. Kościót wobec przemian politycznych w Polsce (1944-1994), Warsaw, 1994; Antoni Dudek and Ryszard Gryz, Komuniści i Kościót w Polsce (1945-1989), Cracow, 2003; Barbara Fijałkowska, Partia wobec religii i Kościoła $w$ PRL, 2 vols, Olsztyn, 1999-2001, vol. 1: 1944-1955, vol. 2, part 1: 1956-1963, vol. 2, part 2: 1964-1970; Zygmunt Zieliński, Kościół w Polsce 1944-2002, Radom, 2003; Jan Żaryn, Dzieje Kościoła katolickiego w Polsce (1944-1989), Warsaw, 2003. Barbara Fijałkowska, who passed away prematurely, did not finish her work. Volume 3 (the last one), covering the years 1971-89, has never been published. This work is not a classic synthesis and has many features of a source publication. 20 to 30 per cent of the text in every volume are party documents. For more recent works, see: Łucja Marek and Monika Bortlik-Dźwierzyńska, Za Marksem bez Boga. Laicyzacja życia społecznego w Polsce w latach 1945-1989, Katowice, 2014.

${ }^{10}$ The live TV broadcast of the inauguration of the pontificate of John Paul II from Rome, on Sunday 22 October 1978, was an unprecedented event on an extraordinary social scale, although on a one-off basis. This way, for the first time in more than 20 years, the Polish TV broadcast a mass. Millions of Poles could hear the greetings which the Pope addressed in Polish for the first time to his compatriots. 
made to 'play' by the previous rules with the Church. On each occasion, the state authorities tried to maximally delay the pilgrimage, interfered in its duration and route, and made explicit attempts to interfere in the content of the homilies delivered by the Pope. For example, in 1983, the Holy Father was prohibited from visiting the Polish coastal cities of Gdańsk, Gdynia and Szczecin, which were most closely involved with the activity of the Solidarity movement. Moreover, the coverage which the pilgrimages received in the Polish Television is also unforgettable.

Firstly, awkward attempts were made to convince the Poles that, for example in 1979, the masses and other celebrations in which John Paul II participated, except for those in Warsaw, Cracow and Auschwitz, were local events only, and therefore were transmitted only by regional TV stations - for example the celebrations in Gniezno were broadcast only in the region of Wielkopolska, those in Częstochowa were covered by the regional TV for Silesia and the Zagłębie Dąbrowskie, and so on. What is more, the live broadcasts were manipulated. The cameramen could only show zoomed-in views of praying priests, nuns and elder people; panoramic views and showing the vast crowds gathered was strictly prohibited. On the other hand, we must not forget that according to the Latin motto pecunia non olet, in 1979 the Polish Television produced full colour footage for sale to foreign TV stations, which showed a true picture of the meetings which John Paul II held with his compatriots.

In the developments of the 1980s in Poland, the Catholic Church had the role of a moderator, and sometimes even an intermediary between the state authorities and the Solidarity Movement. At the same time, it enjoyed more freedom than earlier, especially in terms of the construction of churches and publishing activity. However, the relations with the state authorities were far from normal. We must not forget that the Office for Religious Affairs (Urząd do Spraw Wyznań) continued its operation, and behind the scenes, the Fourth Department of the Ministry of the Interior perpetrated the most talked-about crimes in the 1980s. For millions of Poles, the act of kidnapping and killing Rev. Jerzy Popiełuszko will forever remain a symbol of the so-called disintegration activity of the Ministry of the Interior.

Only in May 1989 did the PRL authorities finally develop a legal basis for their relations with the Catholic Church and muster up the effort to establish official diplomatic relations with the Holy See. Later, during the premiership of Tadeusz Mazowiecki, the Office for Religious Affairs was abolished, and together with the liquidation of the communist Security Service, units within the Ministry of the Interior, in charge of the opposition to the Church, were closed. However, it seems that relatively many 
politicians of the Third Republic of Poland, who had pursued their careers in the Polish United Workers' Party, failed to get rid of their anti-clerical prejudice. As proof, we can look at the fact of blocking the process of ratification of the Concordat in Sejm throughout the years 1993-97, when the coalition of the Democratic Left Alliance (Sojusz Lewicy Demokratycznej SLD) and the Polish People's Party (Polskie Stronnictwo Ludowe - PSL) formed the government. For the sake of exactness, we must add here that for various reasons, including, undoubtedly, political and opportunistic ones, President Aleksander Kwaśniewski, a former member of the SLD, finally signed the Concordat on 23 February 1998. In general, the relations between the Church and the state authorities in the Third Republic of Poland were based on the principle of the so-called friendly neutrality and never, even in the most difficult moments, even remotely resembled those from the best years of the PRL.

However, it is hard to determine to what degree the anti-clerical attitude of part of the left-wing political elite was the outcome of the ideological dogmas of the PRL. The fight against religion, one of the pillars of communism, on the ground of the People's Republic of Poland translated into confrontation with the Catholic Church, defined as an institution rather than a community of the faithful, accompanied by a fight against the clergy and religion understood as the 'opium for masses. ${ }^{11}$ What is interesting, many years later, a relatively large group of my interviewees among former party activists are very critical about that 'anti-clerical obsession' and view it as a grave mistake and one of the key reasons for their party's defeat in historical terms. In their opinion, a fight against the Church in a mostly Catholic society, was bound to fail.

${ }^{11}$ Mieczysław F. Rakowski, who was the last person to hold the post of the First Secretary of the Central Committee of the PZPR, in an interview with Dariusz Wilczak, indicated that this quote from Karl Marx had been falsified: "This is only a half of the sentence: "Religion is opium for the people". It goes on: "Religion is hope for the oppressed in this world" '. (To jest tylko połowa zdania: 'Religia jest opium dla ludu'. Dalej jest: 'Religia jest nadzieją uciśnionych tego świata'). Dariusz Wilczak, Mucha za szybą. Nie dokończona rewolucja, Warsaw, 1997, p. 73. However, Rakowski was not precise either, and his interpretation blurs the meaning of Marx's words. See: Karol Marks, Przyczynek do krytyki heglowskiej filozofii prawa. Wstęp (first published: Deutsch-Französische Jahrbücher, 1844; first published in Polish: K. Marks and F. Engels, Wybrane pisma filozoficzne 18441846, Warsaw, 1949). To quote Marx: 'Religion is the sigh of the oppressed creature, the heart of a heartless world, and the soul of soulless conditions. It is the opium of the people'. and further: 'The abolition of religion as the illusory happiness of the people is the demand for their real happiness'. There is a meaningful difference, introduced by the Bolsheviks, which changes the sense of Marx's idea ('opium for the people' rather than 'opium of the people'). 
Indeed, in spite of ample knowledge of the subject, the amount of measures, time and energy which the Polish communists spent on fighting with Catholicism (notwithstanding the 'historical phase') never ceases to amaze. At the same time, we must not forget that both in terms of the results and the effort made, they could never even compare themselves to their comrades in other countries of real socialism. To make things worse, they were constantly criticized by their 'Soviet comrades' and representatives of other 'sister parties' for not taking a firm enough stance against clerical attitudes in the public life - a euphemism used to describe Poland's more liberal policy towards the Catholic Church.

John Connelly pays attention to a meaningful paradox: 'Ironically, the judgement of Czesław Miłosz that religion had lost its power in Europe after the war was accurate almost everywhere except in his own land. More than ever, the church was considered the bulwark of national culture in Poland. The destruction of its old leadership during the war, and the widespread involvement of priests in the decentralized structures of the underground, had loosened the nexus of church and state, and linked the perceptions and values of the clergy and the people more firmly than ever'. ${ }^{12}$

Church-state relations in the PRL were varied throughout the years. Going through better and worse periods, they were never fully sincere or loyal. Until 1989, the communists never ceased to use terrorist methods, to mention the kidnapping and killing of Rev. Jerzy Popiełuszko in 1984 by three officers of the Fourth Department, or the mysterious deaths of three priests, Stefan Niedzielak, Stanisław Suchowolec and Sylwester Zych in 1989. Owing to the broad range of research conducted at the Institute of National Remembrance, we know today that no other professional or social group in the PRL was under such strict surveillance by the Security Service as the men of the cloth.

It is understandable that representatives of the state authorities and those of the Church worked at cross-purposes, and each party to the conflict wanted to shape the mutual relations in a different way. The state, governed by the Polish United Workers' Party, in spite of various political turbulences, sought to subdue the Catholic hierarchy, and when it turned out to be impossible - at least to minimize the role of the Catholic Church in the public life. The Church, on the other hand, defended the impact it had on the social life. However, occasionally, in return for certain concessions, the Church was ready to maintain tactical neutrality or even support the

${ }^{12}$ John Connelly, Captive University: The Sovietization of East German, Czech, and Polish Higher Education, 1945-1956, Chapel Hill, NC, and London, 2000, p. 73. 
communists. At times, the liberties won in that way were meaningful and important for the society (for example teaching religion at schools or the freedom to pursue religious activities in closed environments, such as hospitals, army, custody facilities or children's summer camps); at other times, they mattered only to the Church (for example tax or duty allowances and exemptions).

Within several decades, the Catholic Church in Poland witnessed twice a thorough system transformation. The first one took place in 1944-45, when the communists seized power, obviously, to a decisive extent, owing to the military power of the Soviet Union. Millions of Soviet soldiers liberated Poland from the occupying Nazi forces, at the same time 'securing' the process of creating a communist dictatorship based mainly (but not exclusively) on violence and terror. The second system transformation was carried out at the end of the 1980s, when the monocentric system saw its end and a democratic country was formed on its rubble.

Obviously, in the PRL, where more than 90 per cent of the population declared themselves Catholic, although an incomparably smaller percentage actively participated in religious practice or lived by the articles of faith, some members or even activists of the Polish United Workers' Party attended church services on a more or less regular basis. The practice was disapproved by the party, especially in the Stalinist era, when the Polish United Workers' Party was relatively most communistic in character. Employees of the 'force sectors' (the army, militia and security service), representatives of the public administration and executives, as well as their family members, were stigmatized and oppressed for showing this type of 'clerical' attitudes. Clandestine weddings, christenings and first communions in churches located miles away from their homes or sometimes even in other towns were not rare in those circles. However, the most serious problem, even for many party leaders, were church funerals of their closest family members, especially their parents, who were faithful and practising Catholics. ${ }^{13}$

Interviewed by Teresa Torańska, Wojciech Jaruzelski admitted that in 1966, during his mother's funeral, he did not enter the church:

I held the function of Head of the General Staff and Deputy Minister of National Defence. [...] There was no doubt that I was going to attend. However, it was a Catholic funeral, my mother was deeply religious. [...] I had spoken with Marshal Spychalski, Minister of National Defence, before I left,

${ }^{13}$ So far, Krzysztof Kosiński has examined these issues in most detail. Krzysztof Kosiński, “"Religianctwo”. Napięcie między ideologią a religią w świadomości członków i działaczy PZPR’, Polska 1944/45-1989. Studia i Materiały, 12, 2014, pp. 107-203. 
and told him that I wanted to attend the funeral. [...] On the following day, he would have found a report on his desk with information that General Jaruzelski was at a Catholic funeral anyway. So I thought that it would be better if I told him myself. He replied: 'Well, it's your decision, but you understand that here, in the army, we do not encourage our officers to attend religious services'.

General Jaruzelski added, that he went to the funeral in plain clothes.

I took one step - I went to the funeral, was at the cemetery and, in fact, took part in the religious funeral of my mother. I did not take the second step - I did not enter the church,

since

it would have been disloyal towards Marshal Spychalski and the Ministry's executives, and immoral towards the subordinates who were strictly advised not to attend this type of services. ${ }^{14}$

With time, apart from secular weddings and funerals, a secular baby naming ceremony was introduced as a lay equivalent of baptism. And so, for example in 1971, when the 'quintuplets of Gdańsk' were born, whose father was a professional soldier and the authorities wanted to emphasize the secular character of the Polish People's Army (Ludowe Wojsko Polskie), a baby naming ceremony of was organized in the Artus Court in Gdańsk. Full colour footage was recorded as a documentary. The children's guardians (lay equivalents of godparents) were, among others, Prime Minister Piotr Jaroszewicz and Minister of National Defence General Jaruzelski.

In the circumstances of constant laicization and atheization of the public life by the communists, the Catholic Church had an extremely difficult role to play. It was the force which most effectively, although not

14 'Byłem wtedy szefem Sztabu Generalnego i wiceministrem obrony narodowej. [...] Nie miałem wątpliwości, że pojadę. Ale to był katolicki pogrzeb. Moja matka była osobą głęboko wierzącą. [...] Przed wyjazdem rozmawiałem z ministrem obrony narodowej marsz. Spychalskim. Poinformowałem go, że chcę jechać. [...] Na drugi dzień i tak miałby na biurku informację, że gen.Jaruzelski był na katolickim pogrzebie. Uznałem, że będzie lepiej, gdy otrzyma ją wcześniej i ode mnie. Odpowiedział: “No, cóż, to jest wasza decyzja, ale rozumiecie, że my w wojsku nie zachęcamy naszych oficerów do uczestnictwa w uroczystościach religijnych". [...] Zrobiłem jeden krok, że na pogrzeb pojechałem, że byłem na cmentarzu i de facto uczestniczyłem w religijnym pochówku mojej matki, ale nie zrobiłem drugiego kroku - nie wszedłem do kościoła [...], byłoby to nielojalne wobec Spychalskiego i kierownictwa resortu. Oraz niemoralne w stosunku do podwładnych, wobec których istniały zasadnicze przeciwwskazania uczestniczenia w podobnych uroczystościach', Teresa Torańska, Byli, Warsaw, 2006, p. 31. 
always consistently, resisted the pressure put by the state authorities. Moreover, for many Poles, the Church was a custodian of the national tradition and, at least to a certain degree, an advocate of the interests of the mostly Catholic population. However, not everyone saw (and sees) it that way.

Let me recall the opinion which Professor Adam Łopatka, PhD in Law, former head of the Office for Religious Affairs in 1982-87, presented at the end of the twentieth century on the policy pursued by the PRL authorities towards the Catholic Church:

The Policy of the Polish Workers' Party (PPR) and the PZPR pursued towards the Catholic Church, as well as other Churches and religious associations, was in the interest of the People's Republic of Poland. It was also beneficial to Churches and religious associations. [...] It was an original Polish policy. It referred to the democratic experience of other countries, especially the USA and France. It always appreciated the values which the Church contributed to the life of the nation - its role in meeting the religious needs of the faithful and creating the national culture - architecture, arts, music, dance and literature. It also appreciated the cultural activities proposed by the Church as a way of spending leisure time, as well as the role of the Church's moral doctrine in shaping peaceful interpersonal and international relations. The state never attempted to interfere in, or even present opinions on religious beliefs, rites, ceremonies or rituals. [...] It was a policy of respect for the religious needs of the faithful, freedom of conscience and religion. It was never anti-religious. ${ }^{15}$

It is hard to believe that, according to the professional bio included in the cited publication, a researcher of international standing could have written something so absurd and untrue. Speaking about freedom

15 ‘Polityka PPR i PZPR w stosunku do Kościoła katolickiego, a także innych Kościołów i związków wyznaniowych, była dyktowana interesami Polski Ludowej. Była również korzystna dla Kościołów i związków wyznaniowych. [...] Była to polska oryginalna polityka. Nawiązywała do demokratycznych doświadczeń innych państw, w szczególności USA i Francji. Polityka ta doceniała zawsze wartości wnoszone przez Kościół do życia narodu: jego rolę w zaspokajaniu potrzeb religijnych ludzi wierzących, rolę kulturotwórczą w dziedzinie architektury, sztuki, muzyki, śpiewu i literatury. Doceniała również wielką rolę Kościoła w zagospodarowywaniu kulturalnie wolnego czasu. Także rolę kościelnej doktryny moralnej w kształtowaniu stosunków między ludźmi oraz rozwijaniu pokojowych stosunków międzynarodowych. Państwo ludowe nigdy nie próbowało ingerować, a nawet tylko wypowiadać się na temat wierzeń czy obrzędów i ceremonii oraz rytuałów religijnych. [...] Była to polityka poszanowania potrzeb religijnych ludzi wierzących, wolności sumienia i wyznania. Nie była nigdy antyreligijna', Adam Łopatka, ‘Polityka PZPR wobec Kościoła katolickiego', in Polska pod rzadami PZPR, ed. Mieczysław F. Rakowski, Warsaw, 2000, pp. 248-49. 
of conscience and religion in the PRL, about appreciation by the state authorities of the culture-forming role of the Catholic Church in the field of architecture (does the author of these words refer to the granting, or rather non-granting, 'after consideration', of permissions for the construction of new churches?), or convincing that the People's Republic of Poland never tried to interfere in religious practice - even more so in the context of the activity of the Office for Religious Affairs and the Fourth Department of the Ministry of the Interior - seems to be a bad joke!

Anyway, the mutual relations between the Church and the state were shaped differently in certain periods. As it has been mentioned before, surprisingly, they were relatively the best at the initial and final periods of the People's Republic of Poland. Initially, the Polish Workers' Party, using the Soviet 'protective umbrella' and proclaiming the strengthening of the democratic system, was slowly but surely gaining a hegemon position in the social life. Under the 'salami tactic'16 of progressive ('slice after slice') elimination of opposing forces, groups and organizations from the political arena, applied by the communists in the Eastern block, for tactical reasons, the communists refrained from an open attack on the Catholic faith and the Church. Nevertheless, the new state authorities broke the Concordat as early as in September 1945. In the initial period, the communists wanted it to be more than a pretence and declared their willingness to maintain freedom of religion in Poland. ${ }^{17}$

What is more, when required ('at a given stage'), the communist dignitaries, including Bolesław Bierut, President of the State National Council, took part in religious services and ceremonies. In 1944, the Day of the Polish Army was still celebrated in the same way as before the war - on 15 August, the anniversary of the victory in the Battle of Warsaw in 1920 and the day of Assumption of Mary..$^{18}$ On this day, the State National Council had its first session in Lublin. The session was adjourned so that the members of the State National Council could attend a ceremonial drumhead service. Bolesław Bierut, Edward Osóbka-Morawski, Chairman of the Polish Committee of National Liberation, and other dignitaries, as

${ }^{16}$ Mátyás Rákosi, the communist dictator in Hungary and Secretary General of the Hungarian Workers' Party, was the author of the phrase 'salami tactic'. He considered himself 'the most loyal of Stalin's students'.

${ }^{17}$ For more on the subject, see: Jan Żaryn, Kościół a władza w Polsce (1945-1950), Warsaw, 1997.

${ }^{18}$ Chaplains served in the army, and the military oath finished with the words 'So help me God'. As late as February 1947, Bierut used the same words to finish his president's oath. 
well as a representative of the Soviet Union, Nikolai Bulganin, ${ }^{19}$ attended the service.

At the same time, the state authorities were trying to convince the society that freedom of religion would not be in any way endangered. On Sundays and Catholic holidays the Polish Radio still broadcast the church service, and everyday broadcasting began with the religious song 'When the early aurora rises' (Kiedy ranne wstaja zorze). Celebrations of commissioning rebuilt or newly built public utility facilities were attended by representatives of the state authorities and almost always by Catholic clergymen of a rank appropriate to the prestige of the event. The same practice was followed at other important state events. However, Bierut did not refrain from strong attacks on the clergy during his conversations with the press secretary Stanisław Łukasiewicz in the Belvedere Palace.

This is how, years later, the latter reported the words of his superior:

Village parish-priests are the main pillars of obscurantism in our country; the Polish clergy is benighted and, unfortunately, still very influential on the population. Bierut himself has a lot of first-hand experience of how greedy and mean village parish-priests can be.

However, he added immediately:

But we are not going to persecute the Church in Poland [...] although this is what priests would like us to do. The Polish nation is Catholic and deeply religious, there are various related celebrations, rites, singing and even outfits. The Catholic faith has become part of the Polish culture. It would be nonsense to eradicate it all. Even I sometimes need to go to church - he smiled.

He also recalled that during a recent annual Corpus Christi procession in Warsaw, he walked arm-in-arm with Marshal Michał 'Rola' Żymierski and Primate August Hlond.

Nevertheless, Bierut explained:

Accepting the Catholic clergy in Poland and its influential position is not equivalent to giving up on our lay concepts, secular outlook on life and propagating lay understanding of the world. We cannot resign from educating our youth according to lay principles, especially in the schools, where anti-dialectics and Catholic fideism, with their stupefying effect, became so deeply rooted during the interwar period. The opposition, in the odour of sanctity, is highly discontent with

${ }^{19}$ Marek Łatyński, Nie paść na kolana. Szkice o polskiej polityce lat powojennych, Wrocław, 2002, p. 664; Tadeusz Żenczykowski, Polska Lubelska 1944, Paris, 1987, pp. 111-12. 
our lay propaganda. In Poland, only religious, Catholic views may be propagated - he commented. ${ }^{20}$

It seems that Bierut's opinions were very biased and unfair towards the Catholics. However, it was a constant trend among the political elites, which prevailed not only in the first years of the People's Republic of Poland.

Although on many occasions the communists had accused the Polish bishops of 'supporting the opposition', and suggested that links existed between the Catholic hierarchy and the parliamentary opposition or even the armed underground groups, in general, until 1948, when the first stage of establishing the Stalin-style communist system in Poland finished, they refrained from attacking the Church and avoided open conflict. ${ }^{21} \mathrm{~A}$ change of course in the policy towards the Catholic Church coincided with the death of Primate Hlond. His successor, the forty-seven-year-old Bishop of Lublin Stefan Wyszyński, understood the undergoing changes, but did not accept them. A reformer and conservative in one person, he turned out to be a challenging and demanding opponent to the communists.

At the same time, Primate Wyszyński knew how to leverage the official authority of Primate in combination with the informal, personal au-

20 'Proboszcz wiejski jest główną podporą ciemnogrodu w naszym kraju, polski kler jest zacofany, i ma, niestety, w dalszym ciągu ogromny wpływ na masy. On, Bierut, nieraz się przekonał na własnej skórze, jak proboszczowie wiejscy potrafią być chciwi i niedobrzy. [...] Ale wcale nie będziemy prześladowali Kościoła w Polsce [...] choć może księża by tego chcieli. Naród polski jest katolicki, przywiązany do swojej wiary, łączą się z tym różnego rodzaju formy obyczajowe, święta, obrzędy, śpiewy, nawet stroje. Katolickie wierzenia w Polsce stały się już jakąś formą kultury polskiej. Byłoby więc nonsensem likwidować to wszystko. Przecież i ja muszę czasami chodzić do kościoła - uśmiechnął się. [...] Pogodzenie się z faktem istnienia w Polsce kleru katolickiego ze wszystkimi jego wpływami nie oznacza wcale, że powinniśmy zrezygnować z naszych koncepcji laickich, z naszego światopoglądu laickiego i z propagandy na rzecz takiego właśnie rozumienia świata. Nie możemy się przecież wyrzec wychowania młodzieży w duchu laickim, szczególnie w naszych szkołach, gdzie antydialektyzm, fideizm katolicki, a więc w istocie myślenie ogłupiające, tak mocno zapuściło korzenie, choćby w okresie dwudziestolecia. O to, że chcemy szerzyć naszą propagandę laicką, udrapowana w różne świętości reakcja ma również do nas wielkie pretensje. W Polsce publicznie można propagować tylko poglądy religijne, katolickie - mówił dalej', Stanisław Łukasiewicz, Byłem sekretarzem Bieruta. Wspomnienia z pracy w Belwederze w latach 1945-1946, Cracow, 1987, p. 40.

${ }^{21}$ Nevertheless, Krystyna Trembicka emphasized in her analyses that from the beginning of the People's Republic of Poland, the communist authorities considered the Church an enemy and fought with it at 'varied intensity'. The particular stages of the fight (and their intensity, scope and duration) always depended on the state and the party, Krystyna W. Trembicka, Wrogowie w myśli politycznej Polskiej Zjednoczonej Partii Robotniczej, Lublin, 2013, p. 136-54. 
thority he earned while serving as Primate. The fact that he served the office for almost 33 years definitely helped him build his authority. In that time, he held many meetings with the first secretaries of the PZPR Central Committee, from Bierut through to Stanisław Kania. Two months before his death, during a deep political and social crisis in March 1981, Cardinal Wyszyński spoke to General Jaruzelski, who took the office of prime minister a few weeks before, and six months later was appointed the First Secretary of the PZPR Central Committee. Possibly, owing to those contacts, Primate Wyszyński, like no one else in the Church circles, knew and understood the communist logic.

However, his extraordinary authority was shaped, to an even greater degree, by his invincible stance in the Stalin era and the experience of imprisonment by the communists. Although the state authorities finally carried out a show trial, for three years he was detained in isolation without a court judgement, and only the last place of detention - the convent of the Sisters of the Holy Family of Nazareth in Komańcza near Sanok did not resemble a typical detention centre. From autumn 1955, Cardinal Wyszyński could contact the outer world, after two years of complete isolation. $^{22}$

However, before the imprisonment of Cardinal Wyszyński, Church-state relations in Poland were deteriorating week after week, for various reasons. Without ranking them as more or less important, one of them was the above mentioned end of the political struggle (and the gradually quieting armed fight) for power. In the aftermath of the communists' victory, the sovietization of the country was gaining momentum. In the process, the agricultural sector was collectivized, the country was being forcefully industrialized, socialist realism was propagated in the arts and culture, youth organizations were monopolized through the establishment of the Polish Youth Association (Związek Młodzieży Polskiej) and the Public Organization 'Service for Poland', the movement of lead workers was established, and so on.

${ }^{22}$ For more information, see: Ewa K. Czaczkowska, Kardynał Wyszyński. Biografia, Cracow, 2013; Andrzej Micewski, Stefan Kardynał Wyszyński (1901-1981), Warsaw, 2000 (it is a practically unchanged version of Kardynał Wyszyński. Prymas i mąż stanu, issued for the first time in Paris in 1982). Cf. Peter Raina, Kardynał Wyszyński, 20 vols, Warsaw, 1993-2010, vol. 1: Droga na Stolicę Prymasowska, 1993, vol. 2: Losy więzienne, 1993, vol. 3: Czasy Prymasowskie 1956-1961, 1994, vol. 4: Czasy Prymasowskie 1962-1963, 1994, vol. 5: Czasy Prymasowskie 1964-1965, 1996, vol. 6: Orędzie biskupów a reakcja władz, 1995, vol. 7: Konflikty roku milenijnego, 1998, vol. 8: Czasy Prymasowskie 1967-1968, 1998, vol. 9: Czasy Prymasowskie 1969-1970, 2003, vol. 10: Czasy Prymasowskie 1971, 2007, vol. 11: Czasy Prymasowskie 1972, 2004, vol. 12: Czasy Prymasowskie 1973, 2004, vol. 13: Czasy Prymasowskie 1974, 2006, vol. 14: Czasy Prymasowskie 1975, 2006, vol. 19: Czasy Prymasowskie 1980, 2010. 
All these developments were accompanied by increasing pressure from the communists in power, who were seeking to gradually eliminate the Catholic clergy from the public life. It seems that not only then, but throughout the forty-five years of the PRL, the main site of confrontation was the influence of the communists and the clergy on young Poles. The two opposing forces were fighting to win people's hearts and minds, then and even more in the forthcoming years. Such was the background for the 'spontaneously' organized anti-clerical protests which swept across the country in the first half of 1949. At the same time, the state authorities ignited conflicts on local and national arenas and demanded that the Catholic hierarchy officially approve of the new political system and call on the faithful to do the same. Further deterioration in mutual relations was influenced by the representation by Pope Pius XII, which threatened Catholic communist party members and well-wishers with excommunication.

The representation was not made public in Poland. However, it prompted the state authorities to issue a decree on the protection of 'freedom of conscience and religion' on 5 August 1949, which threatened imprisonment for the 'abuse of the freedom of religion and conscience for any purpose adverse to the political system' - a concept whose interpretation was completely at the discretion of those in power. The state authorities openly admitted that they intended to interfere in the internal affairs of religious congregations. All these developments were part of a game and forms of pressure exerted on the representatives of the Church. At the same time, what may apparently seem to be a paradox, secret talks were conducted between representatives of the state authorities and the Catholic hierarchy, aimed to conclude an agreement. Initially, neither of the parties was ready for concessions, and the state authorities sought complete subordination of the Catholic hierarchy.

In September 1949, the existing combatant organizations were united into a monopolistic organization named the Society of Fighters for Freedom and Democracy (Związek Bojowników o Wolność i Demokrację), and extended with the Committee of Priests, composed of the so-called patriotic priests. ${ }^{23}$ In January 1950, the government made another step to

${ }^{23}$ The subject has been covered in many publications. See: Bożena Bankowicz, ‘Ruch księży patriotów 1949-1955 czyli “koń trojański” w polskim Kościele katolickim', in eadem and Antoni Dudek, Ze studiów nad dziejami Kościoła i katolicyzmu w PRL, Cracow, 1996, pp. 5-24; Tadeusz Markiewicz, “"Księża patrioci” w latach 1949-1955', in Stosunki między państwem a Kościołem rzymskokatolickim w czasach PRL, ed. Andrzej Chojnowski and Marcin Kula, Warsaw, 1998; Janusz Stefaniak, "Księża patrioci” w latach 
'soften up' the invincible bishops - this is how the decision to unlawfully appoint an administrative receiver at the 'Caritas' Association of Catholics and uproot about one thousand care facilities should be interpreted. Detentions of clergymen became more frequent, mostly based on fictitious charges. On 20 March 1950 the Sejm adopted a law on taking over of the real estate owned by the Church (the so-called mortmain goods). At the same time, it was announced that a failure to adhere to the new law, which was considered an extension of the agricultural reform of September 1944, would be severely punishable, even by death. Possibly, these were the most spectacular examples of secularization of the Church's property in the PRL. It seemed that a state-Church agreement was out of question, when unexpectedly, on 14 April 1950, the 'Agreement between the representatives of the government of the Republic of Poland and the Polish Episcopate' - the first agreement of this type between the communists at power and the Catholic hierarchy - was signed. What is interesting, the Holy See distanced itself from the document, probably due to the fact that Pope Pius XII did not have a thorough understanding of the specific situation of the Church in a Catholic country governed by communists. ${ }^{24}$

On the other hand, however, the Church made serious concessions of far-reaching consequences. It undertook not to oppose the collectivization of the agricultural sector, to call on the faithful to respect the "law and state authorities', agreed to combat the 'criminal activity of underground gangs' and oppose 'any pursuance of war'. By making these undoubtedly meaningful concessions and undertaking to declare loyalty towards the state authorities, the Church leaders took a serious risk. They must have counted on the absolute trust and devotion of the faithful. Nevertheless, they put part of the faithful, especially those better educated, who showed explicitly anti-communist attitudes, to a difficult test.

1945-1953, Przegląd Powszechny, 1999, 3, pp. 321-29; Jan Żaryn, “"Księża patrioci” - geneza powstawania formacji duchownych katolickich', Polska 1944/45-1989. Studia i Materiały, 1, 1995, pp. 123-49; Jacek Żurek, Ruch 'księży patriotów' w województwie katowickim w latach 1949-1956, Warsaw and Katowice, 2009.

${ }^{24}$ See Jan Żaryn, 'Nieznany list prymasa polski Stefana Wyszyńskiego do Stolicy Apostolskiej w sprawie tzw. porozumienia z rządem z 14 kwietnia 1950 roku', Polska 1944/45-1989. Studia i Materiaty, 2, 1997, pp. 291-308; idem, Stolica Apostolska wobec Polski i Polaków w latach 1944-1958 w świetle materiałów ambasady RP przy Watykanie (wybór dokumentów), Warsaw, 1998; idem, Kościót w Polsce w latach przełomu (1953-1958). Relacje ambasadora RP przy Stolicy Apostolskiej, Warsaw, 2000. For more information on the policy of the Holy See towards the countries of the Central and Eastern Europe, see: Hansjakob Stehle, Tajna dyplomacja Watykanu. Papiestwo wobec komunizmu 1917-1991, Warsaw, 1993 (original in German 1993). See also: Agostino Casaroli, Pamiętniki-męczeństwo cierpliwości. Stolica Święta i kraje komunistyczne (1963-1989), Warsaw, 2001 (original in Italian 2000). 
In return for the concessions, the state authorities made some promises. Firstly, they promised to maintain religious education as a school subject, provided that the curriculum would be agreed on in collaboration with the lay authorities. ${ }^{25}$ Religious ministry was maintained in custody facilities and hospitals, and permission to organize traditional pilgrimages and processions was guaranteed. It seems that by entering into that agreement, the Polish bishops intended to gain time and 'survive' the forthcoming more difficult years. Arguably, they had no doubts that the communists would interpret the document in a way most favourable to them and thus consistently restrict the freedom of the Episcopate.

Nevertheless, the relations between the Church and the state authorities did not deteriorate drastically until the turn of 1953-54, when the state authorities refused to issue a passport to Primate Wyszyński for his journey to Rome, where he was to be appointed cardinal. Detentions of clergymen became more frequent, on political (espionage or acting to the detriment of the state) or criminal (alleged theft or abuse) charges. At the peak of the conflict, on 9 February 1953, the state authorities issued a decree on 'the establishment, filling and elimination of clerical posts'. Under the decree, candidates for clerical posts required approval of the state authorities and were obliged to take a vow of loyalty to the state, in the wording which was already in effect. The state authorities were determined to continue their strict policy and crush the 'rebellious' clergymen in a radical way. On 25 September 1953, the Catholic Church in Poland suffered the most terrible blow: late at night, Cardinal Wyszyński was detained at his residence in Warsaw. ${ }^{26}$

${ }^{25}$ Bartosz Kaliski, ‘Walka władz o pełną laicyzację szkolnictwa na przykładzie szkół archidiecezji gnieźnieńskiej’, in Władze wobec Kościołów i związków wyznaniowych w Wielkopolsce w latach 1945-1956, ed. Konrad Białecki, Poznań, 2008, pp. 29-43.

${ }^{26}$ A unique source of information on the period of 'interning' the Primate is Zapiski więzienne by Cardinal Wyszyński, first published in Paris in 1982 and then reissued many times in Poland. A different type of source is Kryptonim 'Ptaszyńska'. Donosy na Prymasa, ed. Marian P. Romaniuk, London, 1993, which includes notes by Sister Maria Graczyk who accompanied Cardinal Wyszyński. See also: Rev. Stanisław Skorodecki, Jestem świadkiem, Szczecin, 1999; Jacek Żakowski, Mroczne wnętrza. Uwięziony Prymas prywatnie w oczach wspótwięźniów i swojej siostry. Maria Leonia Graczyk, ksiąd Stanisław Skorodecki, Julia Wyszyńska, Warsaw, 2000. For a long time, the issue of party agents around the arrested Primate (Sister Maria Graczyk, alias 'Ptaszyńska' and Rev. Stanisław Skorodecki, alias 'Krystyna') was very controversial and triggered strong emotions, mainly due to its moral dimension. More recent works, based on archival sources developed by the Security Service, resolved the uncertainty around this subject. See: Stefan Kardynat Wyszyński Prymas Polski w dokumentach aparatu bezpieczeństwa PRL (1953-1956), ed. Bogdan Piec, Warsaw, 2001; Wiesław J. Wysocki, Osaczanie Prymasa. Kardynat Stefan Wyszyński jako 'podopieczny' aparatu bezpieczeństwa w latach 1953-1956, Warsaw, 2002. See 
While Cardinal Wyszyński was interned, the Episcopate was run by the Bishop of Łódź Michał Klepacz, appointed by the communists. The Communists blackmailed the Episcopate and threatened that any other candidate to the post would be immediately arrested. On 17 December 1953, the Polish bishops, led by Bishop Klepacz, took a humiliating vow of loyalty to the state before Deputy Prime Minister Józef Cyrankiewicz, in the wording as follows:

I do solemnly swear to be loyal to the People's Republic of Poland and its government. I promise to do my best for the development of the People's Republic of Poland and build its strength and safety. I will take every effort to ensure that the clergymen subordinate to me, in the fulfilment of their civic duty, call on the faithful to respect the law and state authorities, to intensify their efforts in the development of the economy and prosperity of the nation. I promise not to undertake any action that might be in conflict with the interest of the People's Republic of Poland or endanger its safety or integrity of its borders. Protecting the welfare and interest of the country, I will seek to clear any danger which, to my knowledge, may be posed on it. ${ }^{27}$

For someone who identifies himself with the Catholic faith and the interest of the Church, reading the text of the vow must be painful even now, after all those years. The Polish bishops had to take the vow while their arch-prelate was 'in isolation', and what is more - before those who had arrested him. The last sentence of the vow, with a little bit of ill will, can be interpreted as coercion to become an informer, even with respect to potential hazards to the People's Republic of Poland. All the priests had to take a similar vow, and those who evaded it, were prohibited from holding their positions in the Church. It seemed that the state authorities achieved their goal and subordinated, at least to a certain degree, the Catholic Church - the last force which opposed them untill

also: Bartłomiej Noszczak, Polityka państwa wobec Kościoła rzymskokatolickiego $w$ Polsce w okresie internowania prymasa Stefana Wyszyńskiego 1953-1956, Warsaw, 2008.

27 ‘Ślubuję uroczyście wierność Polskiej Rzeczypospolitej Ludowej i jej rządowi. Przyrzekam, że uczynię wszystko dla rozwoju PRL oraz umocnienia jej siły i bezpieczeństwa. Dołożę wszelkich starań, aby podległe mi duchowieństwo zgodnie ze swym obowiązkiem obywatelskim w swej działalności duszpasterskiej nawoływało wiernych do poszanowania prawa i władzy państwowej, do wzmocnienia pracy nad rozbudową gospodarki i podniesienia dobrobytu narodu. Przyrzekam, że nie podejmę niczego, co mogłoby być sprzeczne z interesami PRL lub godzić w bezpieczeństwo lub całość jej granic. Dbając o dobro i interes państwa, będę się starał o odwrócenie od niego wszelkich niebezpieczeństw, o których wiedziałbym, że mu zagrażają.' Journal of Laws [Dz. U.] of 1953, no. 10, item 31. 
the end and maintained its distinctiveness. Therefore, the Primate held a grudge (which he never expressed directly) towards the bishops that they did not take a stronger stance against this policy.

There is no doubt that the year 1956 was an especially meaningful turning point in the history of the People's Republic of Poland, examined in all possible contexts - political, social, economic, cultural, and so on. It was also a milestone in the post-war history of relations between the Church and the state. In the autumn, when Władysław Gomułka took over the leadership of the PZPR, the communists, facing a tense situation in Poland, decided to make numerous gestures of reconciliation towards the Catholic population. Firstly, Cardinal Wyszyński was released and immediately afterwards resumed his public and clerical functions. He actively promoted normalization of the relations with the state authorities, which were facilitated owing to the release of many priests, unlawfully imprisoned 'in the previous period'. The operation of the Club of Catholic Intelligentsia (Klub Inteligencji Katolickiej) in major Polish cities - Cracow, Poznań, Toruń, Warsaw and Wrocław - was approved. After the parliamentary election in January 1957, Gomułka agreed to a representation of Catholic MPs of a few people, three of whom (Stefan Kisielewski, Stanisław Stomma and Jerzy Zawieyski) were editors of Tygodnik Powszechny, a weekly Catholic magazine which had just been handed back to its original editors.

In autumn 1956, religious education returned to the schools as an optional subject. Finally, on 31 December 1956, the state authorities announced a new decree on 'the establishment, filling and elimination of clerical posts', under which they granted themselves smaller powers with regard to the internal affairs of the Church. The government also agreed to the resumption of works by Joint Commission of Representatives of the Polish Government and the Polish Episcopal Conference (Komisja Wspólna Rządu i Episkopatu). In comparison to the Stalinist era, the changes were immense. What is more, unlike changes in many other fields, these changes turned out to be relatively permanent. Notwithstanding the subsequent crises, Church-state relations were never again to become as hostile as they were in the first half of the 1950s. Obviously, it does not mean that the communist authorities withdrew from the operation of total laicization and atheization of the state and its institutions. However, they could resume the operation only after the social unrest from mid-1950s had been curbed.

Church-state relations deteriorated again in 1958, when the PZPR leaders and state authorities started to backtrack on the concessions made towards the Church and the faithful during the deep crisis (from the point of 
view of the communists) in autumn 1956. Anti-clerical policy was resumed, although on a scale and in a scope incomparable to that from the years of Stalin. The retrogression of the mutual relations was at least in part due to the rivalry between the Church and the state for the form and character of the Millennium commemoration. The year 1966 marked the thousandth anniversary of the Baptism of Mieszko I, the first ruler of Poland. The date symbolizes the beginning of the documented history of Poland. It was also a highly significant event in the history of the Church in Poland, deemed to be the adoption of Christianity in the Polish territory. Although, with reference to both events, the date is rather symbolic (both the shaping of the country and Christianization of its population were long-term processes rather than one-off events which took place in the year 966), it turned out to be a perfect field of confrontation between the lay and clerical authorities. ${ }^{28}$ In fact, it became a dispute over the historical inheritance of Poland at the end of the twentieth century.

Step by step, the state authorities undertook actions aimed, more or less directly, to diminish the role of Church. Religious ministry was prohibited in secure institutions (custody facilities, the army, hospitals, children's summer camps), the buildings owned by the Church which were not used directly for church services were seized, and high taxes were imposed, which significantly reduced the Church's funds. Restrictions were gradually imposed on religious education in schools until 1961, when the subject was ultimately withdrawn. The state authorities objected to teaching the catechism in church classrooms. ${ }^{29}$ Permissions for the construction of new church facilities were refused, even in locations where no churches existed. ${ }^{30}$

Nevertheless, Church-state relations ultimately collapsed in mid-1960s, driven by several concurrent factors. Firstly, the communist

${ }^{28}$ No monograph has been published so far on the subject of Millennium, although several compilations of documents and a number of introductory or regional publications are available. Apart from volume 7 of the work by Peter Raina, see: Milenium czy Tysiaclecie, ed. Bartłomiej Noszczak, Warsaw, 2006; Obchody milenijne 1966 roku $w$ świetle dokumentów Ministerstwa Spraw Wewnętrznych, ed. Wanda Chudzik et al., Warsaw, 1998; Peter Raina, 'Te Deum' Narodu Polskiego. Obchody Tysiaclecia Chrztu Polski 1966/67, Olsztyn, 1991; Uroczystości milenijne 1966 roku. Sprawozdanie urzędów spraw wewnętrznych, ed. Wanda Chudzik et al., Warsaw, 1996. Cf. Zapomniany rok 1966. W XXX rocznice Milenium Chrztu Polski, ed. Lech Mażewski and Wojciech Turek, Gdańsk, 1996.

${ }^{29}$ For more detail, see: Hanna Konopka, Religia w szkołach Polski Ludowej. Sprawa nauczania religii w polityce państwa (1944-1961), Białystok, 1997.

${ }^{30}$ For more on this type of conflicts, see: Antoni Dudek and Tomasz Marszałkowski, Walki uliczne w PRL 1956-1989, Cracow, 1999, pp. 84-123. See also: Tajne dokumenty Państwo-Kościót 1960-1980, London, 1996. 
authorities adopted a convenient to them interpretation of the output of the Second Vatican Council, and juxtaposed the 'progressive' popes John XXII and Paul VI with 'reactionary' Cardinal Wyszyński. Secondly, the state and the Church authorities engaged in rivalry about the form of commemoration of Poland's Millennium. Thirdly, the Second Vatican Council was closed with the 'Pastoral Letter of the Polish Bishops to their German Brothers' (Orędzie biskupów polskich do ich niemieckich braci $w$ Chrystusowym urzędzie pasterskim), which, a mere twenty years after the end of the Second World War, included the unforgettable words: 'we forgive and ask for forgiveness'. ${ }^{31}$

Although the Polish bishops sent letters to the Episcopal Conferences in fifty-six countries participating in the Vatican Council with invitations to the celebration of the thousandth Anniversary of the Baptism of Poland, it was only this pastoral letter that caused heated reactions on the part of the party leaders and state authorities. The party leaders, including Władysław Gomułka, attacked the Polish bishops with extraordinary violence, mobilizing public opinion against them with the slogan 'we won't forgive, we won't forget'. By the way, it is worth noting here that a large majority of Poles, including practising Catholics, were not ready yet for reconciliation with the Germans and did not understand this deeply Christian message.

However, when the state authorities unleashed an aggressive attack on the Episcopate and alleged the Primate to have dishonourable political purposes and to have betrayed the national interest, a vast majority of Poles supported their priests. Extremely sensitive about relations with Germany, Gomulka considered the Pastoral Letter an interference of the Episcopate in Poland's foreign policy. In his opinion, the Letter was in conflict with the Polish raison d'etat. However, the reaction of party leaders and state authorities must be considered in a broader context of the conflict over the form of the commemoration of the Millennium. Initially, the state authorities used administrative, and later - even political measures to hamper the religious celebration. At the same time, the lay celebration of the thousnadth Anniversary of the Polish State was organized with a flourish. It was the deepest and most permanent conflict between the Church and the state since 1956.

In spite of the fact that the change of the First Secretary of the Central Committee of the PZPR took place in the dramatic circumstances of De-

${ }^{31}$ Piotr Madajczyk, Na drodze do pojednania. Wokół orędzia biskupów polskich do biskupów niemieckich z 1965 roku, Warsaw, 1994; Sławomir Stępień, 'Sobór Watykański II i Orędzie Episkopatu Polski do biskupów niemieckich’, in Milenium czy Tysiąclecie, pp. 40-51. 
cember $1970,{ }^{32}$ relations between the Church and the state, notwithstanding a verbal declaration by the government representatives, remained in practice unchanged. Edward Gierek's team made stronger attempts to use the authority of the Catholic Church for its own purposes, but at the same time did not abandon the idea to come to an agreement with the Vatican behind the Episcopate's back. The Catholic hierarchs, strongly supported by the Holy See, took a decisive stance in the relations with the state authorities which continued their restrictive policy in terms of granting permissions for the construction of churches. However, as the social and economic situation of the country deteriorated, the authorities expressed readiness to seek support in the Catholic Church and consider various desiderata coming from the Church circles.

Were there any aspects of social life in which the interest of the Church and the communists at power converged? It seems that the two opposing forces would often find a common ground in issues related to ethical and moral standards. As an example, let me quote from the record of a conversation between Stanisław Kania, member of the Political Bureau and Secretary of the central Committee of the PZPR, in charge of the relations with the Church, and Bishop Bronisław Dąbrowski, Secretary of the Conference of the Episcopate of Poland. It was neither the first nor the last time that a dignitary at the PZPR and a Catholic hierarch spoke with one voice. The issue was raised by Bishop Dąbrowski and concerned pornography and 'offence against religion in film, theatre and television'. Kania perversely said to the bishop: 'Please, do not get discouraged. Stigmatize in your writings and preaching, but writers and film directors rather than the state authorities. Even the Party cannot beat them, they follow the Western trends and find support among Western artists. We strongly oppose any nudity, pornography and Western fashion trends, where the artist expresses his independence through nudity and disrespect for others'. ${ }^{33}$ At the turn of the 1950s and 1960s, Gomulka and Cardinal Wyszyński also spoke the same language.

${ }^{32}$ For more detail, see: Jerzy Eisler, Grudzień 1970. Geneza, przebieg, konsekwencje, 2nd edn amended and supplemented, Warsaw, 2012.

33 'obrażanie uczuć religijnych w filmie, teatrze, telewizji'; 'Proszę, nie zniechęcajcie się. Piszcie i piętnujcie na kazaniach, ale nie władze, tylko pisarzy, reżyserów. Z nimi i partia nie może sobie poradzić, ulegają modzie Zachodu i w kołach artystów zachodnich mają poparcie. Zdecydowanie jesteśmy przeciwni wszelkiej goliźnie, pornografii i modzie zachodniej, gdzie artysta swoją niezależność pokazuje w goliźnie i obrażaniu innych', Sprawozdanie z rozmowy w Sulejówku z panem Stanisławem Kanią, sekretarzem KC PZPR, 7 II 1977 r., in Peter Raina, Arcybiskup Dąbrowski w stużbie Kościoła i Narodu. Rozmowy z władzami PRL, 2 vols, Warsaw, 1995, vol. 1: 1970-1981, pp. 301-03. 
In general, however, the common ground was not ample. It seems that in the 1960s and 1970s the Primate and some bishops were particularly concerned with the nationalization of the communist ideology. In the opinion of some of the clergy, the catchy national slogans could attract support from a large part of the Catholic population, and in the long term strengthen the power of the communist authorities in Poland. In an attempt to oppose this trend, in 1973 the Episcopate strongly objected the law passed by the Sejm 'on the socialist upbringing of the youth'. The primate stressed that the upbringing of the young generation in Poland needed to be national rather than political party-oriented, since political parties come and go while the nation exists forever. It should be mentioned here that three years later, in response to a protest by the Episcopate, the state authorities quashed one of the provisions of the constitution under which the civil rights were reserved only to those citizens who 'duly' fulfilled their civil duties. The Sejm passed the amendments to the constitution with one abstention - Stanisław Stomma, chairman of the 'Znak' Catholic Deputies' Group abstained in the vote. ${ }^{34}$

It has been mentioned above that a true turning point in the mutual relations occurred only when Cardinal Karol Wojtyła, Archbishop of Cracow, was elected Pope. It was an extraordinary and truly historical moment for millions of Poles. However, the election a citizen of a country pursuing a certain confessional policy as Pope was a challenge to its state authorities. Officially, they should be overcome with joy when a Pole was elected Holy Father. In fact, a Polish Pope was very inconvenient for the communists. They bitterly consoled themselves saying that 'in the end, it is better to have Wojtyła there as Pope than here as Primate'. ${ }^{35}$ They could not oppose the Pope's wish to visit Poland, his home country. During the meetings with 'their Pope' in June 1979, for the first time in many years the people of Poland could feel their strength, see how many of them there were and how powerful they were together. Andrzej Paczkowski described it in a very expressive way: 'The Poles, kneeling before the Pope, at the same time got up from their knees'. Looking back from today's perspective, there is no doubt that the Holy Father 'awakened' his compatriots. A year after his first pilgrimage, the biggest wave of strikes in history swept across Poland and gave rise to the establishment of the Independent and Self-Governing Trade Union 'Solidarity' - the first legal mass organization in the entire Soviet block, independent from the state authorities.

\footnotetext{
${ }^{34}$ Stanisław Stomma, Pościg za nadzieją, Paris, 1991, pp. 160-63.

35 'ostatecznie lepszy Wojtyła jako Papież tam niż jako Prymas tu', Kazimierz Kąkol, Spowiedź 'pogromcy' Kościoła, Olsztyn, 1994, p. 90.
} 
However, paradoxically to a certain extent, Church-state relations did not improve significantly until the declaration of the martial law. Both the new primate, Archbishop Józef Glemp, and - with his permission other representatives of the Episcopate contacted the representatives of the then state authorities on many occasions. The Primate, who lacked the charisma and all the more the authority of his great predecessor in the office, from his first days as primate made working for peace in the country his priority, and called for 'ceasing violence and ending the fratricidal fight'. His reserved (in the opinion of many members and supporters of the Solidarity movement - excessively moderate) stance brought him criticism from some interned or underground union activists. Nevertheless, it should be stressed here that during the martial law years, the role of the Church was absolutely unique. It was the only organization enjoying genuine respect of and authority over the society, which the state authorities did not dare attack openly.

Moreover, it was the Church that ran charitable activity for the interned and arrested activists of the Solidarity opposition and their families. In 1982, the Catholic Church institutions provided asylum to many representatives of culture, arts and science, who often had been very distant from or even hostile to the religious ideology. In 1975, Rev. Wiesław Niewęgłowski and Rev. Tadeusz Uszyński launched a cyclical event named the Week of Christian Culture, which, during the martial law period, gained a special status and contributed to a unique in the history of Poland close encounter of the religious and artistic circles. Another thing is that it was not too long before they took different paths in mid-1980s.

In spite of the fact that part of the clergy did not hide their support for the underground Solidarity movement, in the 1980s, the state authorities developed a different attitude to the Church. Never before in post-war Poland had so many sacral buildings been raised. At the same time, representatives of the Episcopate were in relatively frequent contact with the state authorities. As it turned out later, the experience was very useful in the years 1988-89, when some of the priests could serve as intermediaries between the Solidarity and the state representatives during the initiation of the Round Table Talks. For the Solidarity, they played the role of guarantors that the other party would abide by the rules of negotiations. For the state authorities, they were the factor curbing possible excessive demands of the Solidarity activists. It would have been unimaginable for the bishops to be in the role of mediators even ten years earlier. Although the Church representatives seemed to retain a neutral stance, it is obvious that, to an incomparably greater degree, they identified themselves with 
the interest and rationale of the Solidarity movement rather than those of the communist regime.

The structure of this essay leaves no room for a comparison between the position and standing of the Catholic Church in Poland with that in other countries under the communist regime. However, it is worth mentioning that, in spite of all that has been said, the situation of the Catholic Church in Poland was much better than in any of those countries. The topic has been discussed in many publications. ${ }^{36}$ Certainly, an attempt to compare the degree of de-Christianization in those countries would be even more challenging. Many factors would require consideration, including the degree of secularization of those countries and their societies (especially relevant in the case of Czechoslovakia) before the seizure of power by communists.

Looking at the process of de-Christianization of modern Europe, a clear distinction must be made between the processes of laicization of the societies (occurring at various speeds and in various scopes) and the processes of secularization of institutions and mechanisms of functioning of particular countries. In countries with a long Catholic tradition, both those which have never been under a communist regime, such as France, Spain or Italy, and those where communists ruled for decades, such as Croatia, Poland, or Slovakia, under applicable regulations, the diplomatic representative of the Holy See - the Papal Nuncio - customarily holds the post of dean of the diplomatic corps, although in general (as well in the PRL), this honourable post is held by the ambassador with the longest experience in a given country.

In a discussion of the degree of laicization of modern Europe and Poland as its part, any general conclusions must be made with caution. Indeed, a large part of society pursues a consumerist and hedonistic lifestyle. However, we must not shut our eyes on the ever-present disrespect for human life. Evil and injustice do not seem to diminish. However, we may wonder whether those who, after the terrorist attack on the World Trade Centre in New York on 11 September 2001, spontaneously brought flowers and lit candles in front of embassies in many countries (not only

${ }^{36}$ For example, see: Bohdan Cywiński, Ogniem próbowane. Z dziejów najnowszych Kościoła katolickiego w Europie Środkowo-Wschodniej, 2 vols, Lublin and Rome, 1982-90, vol. 2: '... i was prześladować będą; Andrzej Grajewski, Kompleks Judasza. Kościót zraniony. Chrześcijanie w Europie Środkowo-Wschodniej między oporem a kolaboracja, Poznań, 1999; Represje wobec duchowieństwa kościołów chrześcijańskich w okresie stalinowskim $w$ krajach byłego bloku wschodniego, ed. Jerzy Myszor and Adam Dziurok, Katowice, 2004. 
in Poland), did it as a gesture of solidarity with the victims and sympathy for their families, in protest against the so-far unimaginable crime, or for religious reasons. Maybe for all those reasons, and many others, combined altogether?

Speaking about millions of people turning away from faith and the institutional Church on the Old Continent, we must remember that in December 2004, after the gigantic tsunami in Asia which took about three hundred thousand human lives, including many European tourists on Christmas holiday, ${ }^{37}$ churches in many countries in the world held funeral services attended by the most important personas, including kings, presidents, prime ministers, ministers, and so on. The same happened in the Netherlands in summer 2014, after the Malaysian Airlines passenger plane had been shot down over east Ukraine, and in Germany, after the Germanwings plane had crashed in the French Alps in March 2015. On the other hand, the Netherlands and Germany are commonly believed to be the most advanced in the process of laicization, or even de-Christianization.

Therefore, while Poland may be at times presented in the West as a 'refuge of Catholicism' on the Old Continent, it all depends on the reference point which, in this case, is made up of wealthy, secularized, laicized, democratic and liberal countries of Western Europe, often with a Protestant tradition. Anyway, notwithstanding whether and to what degree referring to Poland as a 'refuge of Catholicism' is justified, there are many reasons for this state of things. Apart from the common Western ignorance, fed with outdated stereotypes, and Poland's unquestionable economic underdevelopment in comparison with the wealthiest and most developed countries of the West, the opinion is partially a consequence of the decision taken by Cardinal Wyszyński and the Episcopate in the 1960s to delay the implementation of the outcome of the Second Vatican Council in Poland and limit its scope. The reasoning behind the decision, contrary to some opinions, was based not so much on the conservatism of the Primate and Polish bishops, as on the situation in which the Catholic Church found itself in non-democratic and non-independent Poland.

Confronted by centralized, almost monolithic and monopolistic authorities headed, in one person, by Władysław Gomułka, Cardinal Wyszyński could not afford any experiment or even partial decentralization of his authority. It seems that for similar reasons, he was concerned by

${ }^{37}$ The previous time when more Swedes died in one day was on 8 July 1709 at the Battle of Poltava. 
the strengthening role of laity, which - in his opinion - threatened the unity of the Church. However, with time, all these factors combined together led to a certain state of hibernation, freezing (at least in part) of the Catholicism in Poland in its shape from before the Council, and strengthening of the Catholic folklore based on the cult of Mary. Let me be clear - I do not consider this Catholic trend to be improper or inferior. What is more, in the reality of the period preceding the pontificate of John Paul II, this type of religious cult may have protected the Polish Church and society from laicization, and maybe even de-Christianization.

(Translated by Paulina Dzwonnik)

\section{Summary}

The intention of this text was to consider on and attempt to resolve questions whether and to what degree the laicization policy and atheization campaign conducted by successive political teams in Poland after the Second World War contributed to and accelerated the de-Christianization of the Polish society, a process observed also in other European countries. What factors (political, social, economic, cultural, and so on) drove, and what factors delayed or even hampered the processes? What was the role of the Polish Episcopate and its long-term head - Cardinal Stefan Wyszyński, the Primate of Poland, who intentionally delayed the transference of the accomplishments of the Second Vatican Council onto the Polish ground? Another significant issue is the character and intensity of the processes in question. Did they contribute to the modernization of the state and society, or - maybe on the contrary - did they contribute to the preservation of the status quo?

The author paid considerable attention to mutual Church-state relations in communist-ruled Poland. At no time during the communist era in Poland did they resemble partner relations; nevertheless, they indubitably evolved. Their transformation resulted from the domestic developments and changes on the international arena. The foremost premise of all vicissitudes affecting the relations between the Church and the state in post-war Poland (the election of Cardinal Karol Wojtyła as Pope, 1978) had both domestic and international dimensions.

(Translated by Aleksandra Rodzińska-Chojnowska)

\section{Bibliography}

Anusz, Anna, and Andrzej Anusz, Samotnie wśród wiernych. Kościót wobec przemian politycznych w Polsce (1944-1994), Warsaw: Alfa Wero, 1994.

Bankowicz, Bożena, 'Ruch księży patriotów 1949-1955 czyli "koń trojański” w polskim Kościele katolickim', in Bożena Bankowicz and Antoni Dudek, Ze studiów nad dziejami Kościoła i katolicyzmu w PRL, Cracow: PiT, 1996, pp. 5-24. 
Casaroli, Agostino, Il martirio della pazienza. La Santa Sede e i paesi comunisti (19631989), ed. Carlo Felice Casula and Giovanni Maria Vian, Torino: Einaudi, 2000.

Connelly, John, Captive University: The Sovietization of East German, Czech, and Polish Higher Education, 1945-1956, Chapel Hill, NC, and London: University of North Carolina Press, 2000.

Cywiński, Bohdan, Ogniem próbowane. Z dziejów najnowszych Kościoła katolickiego w Europie Środkowo-Wschodniej, 2 vols, Lublin: Redakcja Wydawnictw KUL; Rome: Papieski Instytut Studiów Kościelnych; Fundacja Jana Pawła II. Polski Instytut Kultury Chrześcijańskiej, 1982-90, vol. 2: '... i was prześladować będą. Czaczkowska, Ewa K., Kardynał Wyszyński. Biografia, Cracow: Znak, 2013.

Dudek, Antoni, and Ryszard Gryz, Komuniści i Kościół w Polsce (1945-1989), Cracow: Znak, 2003.

Dudek, Antoni, and Tomasz Marszałkowski, Walki uliczne w PRL 1956-1989, Cracow: Geo, 1999.

Eisler, Jerzy, Grudzień 1970. Geneza, przebieg, konsekwencje, 2nd edn amended and supplemented, Warsaw: Instytut Pamięci Narodowej - Komisja Ścigania Zbrodni przeciwko Narodowi Polskiemu, 2012.

Fijałkowska, Barbara, Partia wobec religii i Kościoła w PRL, 2 vols, Olsztyn: Uniwersytet Warmińsko-Mazurski, 1999-2001, vol. 1: 1944-1955, vol. 2, part 1: 1956 1963, vol. 2, part 2: 1964-1970.

Grajewski, Andrzej, Kompleks Judasza. Kościół zraniony. Chrześcijanie w Europie Środkowo-Wschodniej między oporem a kolaboracja, Poznań: W Drodze, 1999.

Kaliski, Bartosz, 'Walka władz o pełną laicyzację szkolnictwa na przykładzie szkół archidiecezji gnieźnieńskiej’, in Władze wobec Kościołów i związków wyznaniowych w Wielkopolsce w latach 1945-1956, ed. Konrad Białecki, Poznań: Oddział Instytutu Pamięci Narodowej - Komisji Ścigania Zbrodni przeciwko Narodowi Polskiemu w Poznaniu, 2008, pp. 29-43.

Kąkol, Kazimierz, Spowiedź ‘pogromcy’ Kościoła, Olsztyn: Ethos, 1994.

Konopka, Hanna, Religia w szkołach Polski Ludowej. Sprawa nauczania religii w polityce państwa (1944-1961), Białystok: Wydawnictwo Uniwersytetu w Białymstoku, 1997.

Kosiński, Krzysztof, “ “Religianctwo”. Napięcie między ideologią a religią w świadomości członków i działaczy PZPR', Polska 1944/45-1989. Studia i Materiały, 12, 2014, pp. 107-203.

Kryptonim 'Ptaszyńska'. Donosy na Prymasa, ed. Marian P. Romaniuk, London: Puls Publications, 1993.

Kupiecki, Robert, 'Natchnienie milionów'. Kult Józefa Stalina w Polsce 1944-1956, Warsaw: Wydawnictwa Szkolne i Pedagogiczne, 1993.

Łatyński, Marek, Nie paść na kolana. Szkice o polskiej polityce lat powojennych, Wrocław: Towarzystwo Przyjaciół Ossolineum, 2002.

Łopatka, Adam, ‘Polityka PZPR wobec Kościoła katolickiego’, in Polska pod rządami PZPR, ed. Mieczysław F. Rakowski, Warsaw: Profi, 2000, pp. 233-51.

Łukasiewicz, Stanisław, Byłem sekretarzem Bieruta. Wspomnienia z pracy $w$ Belwederze w latach 1945-1946, Cracow: Krajowa Agencja Wydawnicza, 1987. 
Madajczyk, Piotr, Na drodze do pojednania. Wokół orędzia biskupów polskich do biskupów niemieckich z 1965 roku, Warsaw: Wydawnictwo Naukowe PWN, 1994.

Marek, Łucja, and Monika Bortlik-Dźwierzyńska, Za Marksem bez Boga. Laicyzacja życia społecznego w Polsce w latach 1945-1989, Katowice: Instytut Pamięci Narodowej - Komisja Ścigania Zbrodni przeciwko Narodowi Polskiemu, 2014.

Makowski, Janusz, Kościót Francji. Wśród kontrowersji i osiagnięć katolicyzmu francuskiego, Warsaw: Novum, 1969.

Markiewicz, Tadeusz, “Księża patrioci” w latach 1949-1955', in Stosunki między Państwem a Kościołem rzymskokatolickim w czasach PRL, ed. Andrzej Chojnowski and Marcin Kula, Warsaw: DiG, 1998, pp. 69-126.

Marks, Karol, and Fryderyk Engels, Wybrane pisma filozoficzne 1844-1846, Warsaw: Książka i Wiedza, 1949.

Marx, Karl, 'Zur Kritik der Hegelschen Rechtsphilosophie. Einleitung', Deutsch-Französische Jahrbücher, 1844 〈http://mlwerke.de/me/me01/me01_378.htm〉 [accessed 19 October 2017].

Micewski, Andrzej, Stefan Kardynał Wyszyński (1901-1981), Warsaw: Ludowa Spółdzielnia Wydawnicza, 2000.

Milenium czy Tysiaclecie, ed. Bartłomiej Noszczak, Warsaw: Instytut Pamięci Narodowej - Komisja Ścigania Zbrodni przeciwko Narodowi Polskiemu, 2006.

Noszczak, Bartłomiej, Polityka państwa wobec Kościoła rzymskokatolickiego w Polsce w okresie internowania prymasa Stefana Wyszyńskiego 1953-1956, Warsaw: Instytut Pamięci Narodowej - Komisja Ścigania Zbrodni przeciwko Narodowi Polskiemu, 2008.

Obchody milenijne 1966 roku w świetle dokumentów Ministerstwa Spraw Wewnętrznych, ed. Wanda Chudzik et al., Warsaw: Ministerstwo Spraw Wewnętrznych i Administracji; Rytm, 1998.

Osęka, Piotr, My, ludzie z Marca. Autoportret pokolenia '68, Wołowiec: Wydawnictwo Czarne; Instytut Studiów Politycznych Polskiej Akademii Nauk, 2015.

Raina, Peter, Arcybiskup Dąbrowski w służbie Kościoła i Narodu. Rozmowy z władzami PRL, 2 vols, Warsaw: Książka Polska, 1995, vol. 1: 1970-1981.

Raina, Peter, Kardynał Wyszyński, 20 vols, Warsaw (1-20) and Biała Podlaska (15-20): Książka Polska (1-6), von boroviecky (7-14) and Arte (15-20), 19932010, vol. 1: Droga na Stolicę Prymasowska, 1993, vol. 2: Losy więzienne, 1993, vol. 3: Czasy Prymasowskie 1956-1961, 1994, vol. 4: Czasy Prymasowskie 1962-1963, 1994, vol. 5: Czasy Prymasowskie 1964-1965, 1996, vol. 6: Orędzie biskupów a reakcja władz, 1995, vol. 7: Konflikty roku milenijnego, 1998, vol. 8: Czasy Prymasowskie1967-1968, 1998, vol. 9: Czasy Prymasowskie 1969-1970, 2003, vol. 10: Czasy Prymasowskie 1971, 2007, vol. 11: Czasy Prymasowskie 1972, 2004, vol. 12: Czasy Prymasowskie 1973, 2004, vol. 13: Czasy Prymasowskie 1974, 2006, vol. 14: Czasy Prymasowskie 1975, 2006, vol. 19: Czasy Prymasowskie 1980, 2010.

Raina, Peter, ‘Te Deum' Narodu Polskiego. Obchody Tysiąclecia Chrztu Polski 1966/67, Olsztyn: Warmińskie Wydawnictwo Diecezjalne, 1991.

Represje wobec duchowieństwa kościołów chrześcijańskich w okresie stalinowskim w kra- 
jach byłego bloku wschodniego, ed. Jerzy Myszor and Adam Dziurok, Katowice: Księgarnia Św. Jacka, 2004.

Rykowski, Zbysław, and Wiesław Władyka, Polska próba. Październik '56, Cracow: Wydawnictwo Literackie, 1989.

Skorodecki, Stanisław, Jestem świadkiem, Szczecin: Dokument; Zamek Książąt Pomorskich, 1999.

Stefan Kardynał Wyszyński Prymas Polski w dokumentach aparatu bezpieczeństwa PRL (1953-1956), ed. Bogdan Piec, Warsaw: Verbinum, 2001.

Stefaniak, Janusz, “"Księża patrioci” w latach 1945-1953’, Przegląd Powszechny, 1999, 3, pp. 321-29.

Stehle, Hansjakob, Die Ostpolitik des Vatikan: Geheimdiplomatie der Päpste von 1917 bis heute, Bergisch Gladbach: Gustav Lübbe Verlag, 1983.

Stomma, Stanisław, Pościg za nadzieją, Paris: Editions Spotkania, 1991.

Tajne dokumenty Państwo-Kościół 1960-1980, London: Aneks, 1996.

Torańska, Teresa, Byli, Warsaw: Świat Książki, 2006.

Trembicka, Krystyna W., Wrogowie w myśli politycznej Polskiej Zjednoczonej Partii Robotniczej, Lublin: Wydawnictwo Uniwersytetu Marii Curie-Skłodowskiej, 2013.

Uroczystości milenijne1966 roku. Sprawozdania urzędów spraw wewnętrznych, ed. Wanda Chudzik et al., Warsaw: Książka i Wiedza, 1996.

Wilczak, Dariusz, Mucha za szybą. Nie dokończona rewolucja, Warsaw: Most and Ikar, 1997.

Wysocki, Wiesław Jan, Osaczanie Prymasa. Kardynał Stefan Wyszyński jako "podopieczny’ aparatu bezpieczeństwa w latach 1953-1956, Warsaw: Rytm, 2002.

Wyszyński, Stefan, Zapiski więzienne, Warsaw: Soli Deo, 2006.

Zieliński, Zygmunt, Kościół w Polsce 1944-2002, Radom: Polwen, 2003.

Zapomniany rok 1966. W XXX rocznicę Milenium Chrztu Polski, ed. Lech Mażewski and Wojciech Turek, Gdańsk: Instytut Konserwatywny im. E. Burke’a, 1996.

Żakowski, Jacek, Mroczne wnętrza. Uwięziony Prymas prywatnie w oczach współwięźniów i swojej siostry. Maria Leonia Graczyk, ksiądz Stanisław Skorodecki, Julia Wyszyńska, Cracow: Sic!, 2000.

Żaryn, Jan, Dzieje Kościoła katolickiego w Polsce (1944-1989), Warsaw: Neriton; Instytut Historii PAN, 2003.

Żaryn, Jan, Kościół a władza w Polsce (1945-1950), Warsaw: DiG, 1997.

Żaryn, Jan, Kościół w Polsce w latach przełomu (1953-1958). Relacje ambasadora RP przy Stolicy Apostolskiej, Warsaw: Neriton and Instytut Historii PAN, 2000.

Żaryn, Jan, " "Księża patrioci” - geneza powstawania formacji duchownych katolickich', Polska 1944/45-1989. Studia i Materiały, 1, 1995, pp. 123-49.

Żaryn, Jan, 'Nieznany list prymasa polski Stefana Wyszyńskiego do Stolicy Apostolskiej w sprawie tzw. porozumienia z rządem z 14 kwietnia 1950 roku', Polska 1944/45-1989. Studia i Materiały, 2, 1997, pp. 291-308.

Żaryn, Jan, Stolica Apostolska wobec Polski i Polaków w latach 1944-1958 w świetle materiałów ambasady RP przy Watykanie (wybór dokumentów), Warsaw: Instytut Historii PAN, 1998. 
Żenczykowski, Tadeusz, Polska Lubelska 1944, Paris: Editions Spotkania, 1987.

Żurek, Jacek, Ruch 'księży patriotów' w województwie katowickim w latach 1949-1956, Warsaw and Katowice: Instytut Pamięci Narodowej - Komisja Ścigania Zbrodni przeciwko Narodowi Polskiemu, 2009.

Biography: Jerzy Eisler - Professor at the Tadeusz Manteuffel Institute of History of the Polish Academy of Sciences in Warsaw; Director of the Warsaw branch office of the Institute of National Remembrance - Commission for the Prosecution of Crimes against the Polish Nation (IPN); scholarly interests: political history of the France and Poland in the twentieth century, history of the communism, history of military affairs. E-mail: jerzy.eisler@ipn.gov.pl. 